\title{
Environmental Engineering, Land
}

National Cancer Institute

\section{Source}

National Cancer Institute. Environmental Engineering, Land. NCI Thesaurus. Code C18764.

Environmental eng ineering focusing on issues related to land management and pollution remediation. 